Ayuni Diah Melani, Laelatur Rosyidah, Dhiya Restu Putra, Alfan Muhyar Faza - Analisis Makna dalam Geguritan "Iki Gurite Sepi" Karya Surtikanti (Suatu Kajian Semiotika Riffaterre)

\title{
ANALISIS MAKNA DALAM GEGURITAN IKI GURITE SEPI KARYA SURTIKANTI (SUATU KAJIAN SEMIOTIKA RIFFATERRE)
}

\author{
Ayuni Diah Melani \\ Universitas Sebelas Maret, Surakarta, Indonesia \\ Email: ayuni.d.lautner@gmail.com \\ Laelatur Rosyidah \\ Universitas Sebelas Maret, Surakarta, Indonesia \\ Email: laelarosyi@gmail.com \\ Dhiya Restu Putra \\ Universitas Sebelas Maret, Surakarta, Indonesia \\ Email: dhiyarestu2607@gmail.com \\ Alfan Muhyar Faza \\ Universitas Sebelas Maret, Surakarta, Indonesia \\ Email: Alfanmuhyar@student.uns.ac.id
}

Article history:

Submitted June 26, 2021

Revised July 13, 2021

Accepted Nov 18, 2021

Published Dec 21, 2021

\begin{abstract}
This study aims to describe a sign and implied meaning in Surtikanti's Geguritan Iki Gurite Sepi poetry. The approach used in this study is a semiotic approach based on Michael Riffaterre's model. Based on Riffaterre's semiotic approach, the data in this study were analyzed by: 1) Heuristic reading; 2) Hermeneutic Reading; 3) Indirectness of expression; 4) Matrix, model, and variant of poetry; 5) Hypogram. The method used is descriptive qualitative which produces descriptive qualitative data in the form of words, phrases, and sentences contained in poetry. The results of this study indicate that the semiotics used in the study of Javanese poetry or geguritan entitled Geguritan iki, gurite sepi by Surtikanti's has markers and signifiers in it.
\end{abstract}

Keywords: geguritan; meaning of poetry; semiotics Riffaterre 
Ayuni Diah Melani, Laelatur Rosyidah, Dhiya Restu Putra, Alfan Muhyar Faza - Analisis Makna dalam Geguritan "Iki Gurite Sepi" Karya Surtikanti (Suatu Kajian Semiotika Riffaterre)

\begin{abstract}
ABSTRAK
Penelitian ini bertujuan untuk mendeskripsikan sebuah tanda dan makna tersirat dalam puisi berjudul Geguritan Iki Gurite Sepi karya Surtikanti. Pendekatan yang digunakan dalam penelitian ini adalah pendekatan semiotika yang didasarkan pada model Michael Riffaterre. Berdasarkan pendekatan semiotika model Riffaterre, data dalam penelitian ini dianalisis dengan: 1) Pembacaan heuristik; 2) Pembacaan Hermeneutik; 3) Ketidaklangsungan ekspresi; 4) Matriks, model, dan varian puisi; 5) Hipogram. Metode yang digunakan adalah deskriptif kualitatif yang menghasilkan data berbentuk kata, frasa, dan kalimat yang terdapat dalam puisi. Hasil penelitian ini menunjukkan bahwa semiotika yang digunakan dalam pengkajian puisi Jawa atau geguritan yang berjudul Geguritan Iki, Gurite Sepi karya Surtikanti memiliki penanda dan petanda di dalamnya.
\end{abstract}

Kata kunci : geguritan; makna geguritan; semiotika Riffaterre

\title{
PENDAHULUAN
}

Karya sastra merupakan ungkapan pribadi manusia yang berupa pengalaman, pemikiran, perasaan, ide, semangat, keyakinan dalam suatu bentuk gambaran kehidupan, yang dapat membangkitkan pesona dengan alat bahasa dan dilukiskan dalam bentuk tulisan. Salah satu wujud karya sastra yaitu puisi atau geguritan. Puisi merupakan karya sastra yang termasuk dalam golongan lirik, dibandingkan dengan karya sastra lain puisi memiliki bahasa yang lebih ringkas dan indah. Selain itu pemaknaan puisi lebih multitafsir, sehingga masing-masing individu bisa saja memiliki intepretasinya sendiri-sendiri.

Menurut Pradopo (2009: 7) puisi mengekspresikan pemikiran yang membangkitkan perasaan, yang merangsang imajinasi panca indera dalam susunan yang berirama. Selanjutnya menurut Tarigan (dalam Ulya dan Suryanto, 2009:46) puisi didefinisikan sebagai hasil seni sastra, yang kata-katanya disusun menurut syarat-syarat tertentu dengan menggunakan irama, sajak dan kadang-kadang kata kiasan.

Dalam kesusastraan Jawa modern puisi Jawa modern disebut dengan geguritan. Geguritan berasal dari kata gurit yang berarti "tulisan tatahan, kidung dan tembang". Sedangkan geguritan berarti tembang (uran-uran) yang berwujud 
Ayuni Diah Melani, Laelatur Rosyidah, Dhiya Restu Putra, Alfan Muhyar Faza - Analisis Makna dalam Geguritan "Iki Gurite Sepi" Karya Surtikanti (Suatu Kajian Semiotika Riffaterre)

purwakanthi (Poerwadarminta, 1939: 157). Selain itu, geguritan didalamnya tidak terikat pada konvensi-konvensi tertentu layaknya tembang macapat, sehingga bersifat lebih bebas.

Beragam fenomena yang ada pada lingkungan sekitar atau bahkan keadaan jiwa pengarangpun mampu digubah menjadi sebuah karya puisi atau geguritan oleh penyair itu sendiri. Seperti halnya geguritan yang berjudul Geguritan Iki, Gurite Sepi karya Surtikanti jika dibaca sekilas geguritan tersebut merupakan sebuah jembatan yang digunakan oleh penyair untuk meluapkan segala emosi yang dirasakannya. Namun, untuk menelaah lebih dalam mengenai apa makna yang terkandung dalam geguritan karya Surtikanti, perlu dilakukan sebuah analisis terlebih dahulu. Mengingat bahwasanya struktur karya sastra itu sangatlah kompleks dan multitafsir.

Menurut Culler setiap puisi yang dibuat oleh penyair tentu memiliki makna dan arti di dalamnya yang tidak diketahui secara implisit. Menganalisis sastra adalah usaha-usaha menangkap makna dan memberi makna kepada teks karya sastra (puisi) (dalam Pradopo, 2012: 141). Oleh karena itu penulis tertarik untuk menganalisis karya sastra berupa geguritan yang berjudul Geguritan Iki, Gurite Sepi karya Surtikanti menggunakan teori semiotika Riffaterre, dengan menggunakan analisis tersebut maka makna-makna yang terdapat dalam geguritan dapat diurai secara menyeluruh.

Semiotika berasal dari akar kata seme, semeion (Yunani) yang berarti tanda. Nasution (2014: 5) menerangkan ilmu yang secara sistematik mempelajari tandatanda dan lambang-lambang, sistem-sistem lambang dan proses-proses perlambangannya diistilahkan dengan semiotika. Sedangkan, Ratih (2016: 5) menerangkan bahwa Semiotika Riffaterre mengemukakan metode pemaknaan yang khusus, yaitu dengan memberi makna karya sastra sebagai sistem tanda-tanda itu, istilahnya memproduksi makna tanda-tanda. Riffaterre (dalam Ratih, 2016: 5) menjelaskan puisi merupakan aktivitas bahasa yang berbeda dengan pemakaian bahasa pada umumnya.

Puisi senantiasa berbicara mengenai sesuatu secara tidak langsung dengan menyembunyikannya ke dalam suatu tanda. Oleh karena itu, Semiotika Riffaterre 
Ayuni Diah Melani, Laelatur Rosyidah, Dhiya Restu Putra, Alfan Muhyar Faza - Analisis Makna dalam Geguritan "Iki Gurite Sepi" Karya Surtikanti (Suatu Kajian Semiotika Riffaterre)

inilah yang paling tepat digunakan dalam sajak karena analisisnya mengarah pada pemberian makna sebuah karya sastra (sajak). Ada empat hal yang dikemukakan Riffaterre dalam memproduksi makna puisi, yaitu (1) ketidaklangsungan ekspresi puisi (karya sastra) yang disebabkan oleh pergeseran makna (displacing of meaning), perusakan atau penyimpangan makna (distorting of meaning), dan penciptaan makna (creating of meaning), (2) pembacaan heuristik dan hermeneutik, (3) matriks, model, dan varian, dan (4) hipogram (hypogram) atau hubungan intertekstual. Berdasarkan paparan di atas penulis tertarik untuk menganalisis geguritan yang berjudul Geguritan Iki, Gurite Sepi karya Surtikanti menggunakan analisis semiotika Michael Riffaterre.

Beberapa hasil penelitian yang telah mengkaji dari segi semiotika dalam geguritan dengan teori Riffaterre adalah Yoseph Yapi Taum (2007) dengan judul "Semiotika Riffaterre dalam 'Bulan Ruwah' Subagio Sastrowardoyo". Hasil penelitian ini adalah pemahaman arti puisi yang beraneka ragam dapat diminimalisasikan. Melalui tahap-tahap pembacaannya/ pemahaman arti puisi yang beraneka ragam harus bergerak lebih jauh untuk memperoleh kesatuan maknanya. Interpretasi harus bergerak dari divergensi (arti yang heterogen) ke konvergensi (makna yang homogen).

Selain itu, penelitian lain dilakukan oleh Ranti Maretna Huri, Yenni Hayati, dan M. Ismail Nasution (2017) dengan judul "Analisis Semiotika Riffaterre dalam Puisi Dongeng Marsinah Karya Sapardi Djoko Damono". Hasil penelitian ini adalah ditemukannya makna puisi secara utuh dan menunjukkan latar belakang terciptanya puisi Dongeng Marsinah karya Sapardi Djoko Damono.

Beberapa penelitian tersebut ditemukan perbedaan. Penelitian pertama fokus pada kesamaan pandangan ilmiah dalam pemaknaan suatu karya sastra. Sedangkan pada penelitian kedua focus pada menemukan makna puisi secara utuh dan menunjukkan latar belakang penciptaan puisi. Penelitian ini dianggap penting karena pertama peneltian terhadap geguritan dengan menggunakan teori semiotika Riffaterre masing jarang. Kedua Geguritan Iki, Gurite Sepi karya Surtikanti belum pernah dijadikan objek penelitian. 


\section{TEORI DAN METODE PENELITIAN}

Menurut Widodo (2013: 33) Guritan berasal dari kata gurit, tembang, kidung, rerepen dan dapat dibentuk menjadi anggurit dan anggegurit. Dilihat dari bentuknya kata geguritan atau guguritan adalah bentuk dwipurwa pengulangan suku kata awal. Kemudian Padmosoekotjo (1960: 19) memberi penjelasan Tembung guritan linggane gurit, tegese kidung utawa tembang. Ana tembung gurit kang ateges tulisan utawa tatahan. Kata guritan berasal dari kata gurit, yang artinya kidung atau tembang. Selain itu, kata gurit memiliki arti tulisan atau ukiran.

Lebih lanjut, Purwadi (2012: 455) menyatakan geguritan termasuk ke dalam puisi modern dalam sastra Jawa gagrag anyar. Geguritan gagrag anyar keluar dari aturan-aturan seperti dalam tembang, parikan, wangsalan, dan lainlainnya. Dibandingkan dengan parikan, wangsalan, atau tembang, geguritan lebih mudah dipahami. Hal ini terjadi karena geguritan tidak mengikuti kaidah konvensional seperti guru gatra, guru lagu, ataupun guru wilangan. Dari beberapa pengertian di atas dapat disintesiskan bahwa geguritan merupakan puisi Jawa yang tidak terikat oleh aturan dan bahasanya menggunakan bahasa Jawa modern.

Riffaterre mengatakan dalam bukunya Semiotic of Poetry (1978: 1) bahwa puisi selalu berubah oleh konsep estetik dan mengalami evolusi selera sesuai perkembangan jaman. Namun, satu hal yang tidak berubah adalah puisi menyampaikan pesan secara tidak langsung. Puisi mengatakan satu hal dan berarti yang lain. Puisi merupakan sistem tanda yang mempunyai satuansatuan tanda (yang minimal) yang mempunyai makna berdasarkan konvensikonvensi (dalam) sastra (Pradopo, 2003: 122). Untuk itu, dalam sistem tanda tersebut harus dianalisis untuk menentukan maknanya. Riffaterre mengungkapkan bahwa ada beberapa hal yang perlu diperhatikan untuk mengetahui makna puisi secara utuh antara lain: 
Ayuni Diah Melani, Laelatur Rosyidah, Dhiya Restu Putra, Alfan Muhyar Faza - Analisis Makna dalam Geguritan "Iki Gurite Sepi" Karya Surtikanti (Suatu Kajian Semiotika Riffaterre)

\section{Ketidaklangsungan Ekspresi}

Karya sastra dalam hal ini puisi menggunakan bahasa sebagai mediumnya. Bahasa berkedudukan sebagai bahan dalam hubungannya dengan sastra disebut sebagai sistem semiotik tingkat pertama karena sudah memiliki sistem dan konvensi sendiri. Sedangkan, sastra disebut sebagai sistem semiotik tingkat kedua karena sastra memiliki sistem dan konvensi sendiri yang mempergunakan bahasa (Pradopo, 2003: 121). Seperti yang dikatakan Riffaterre bahwa puisi mengatakan sesuatu tetapi memiliki makna yang lain. Artinya, puisi menyampaikan sesuatu secara tidak langsung. Ketidaklangsungan ekspresi tersebut menurut Riffaterre (1978: 2) disebabkan oleh tiga hal, yaitu (1) pergantian arti (displacing of meaning), (2) penyimpangan arti (distorting of meaning), (3) penciptaan arti (creating of meaning).

\section{Pembacaan Heuristik}

Pembacaan heuristik merupakan langkah pertama dalam memaknai puisi secara semiotik. Menurut Pradopo (2003: 135) pembacaan heuristik adalah pembacaan berdasarkan struktur bahasanya atau secara semiotik adalah berdasarkan konvensi sistem semiotik tingkat pertama. Dalam puisi sering kali ditemukan kata-kata yang tidak dipakai dalam bahasa sehari-hari dan “keanehan” stuktur kata. Pada tahap pembacaan heuristik arti kata-kata dan sinonim-sinonim diterjemahkan atau diperjelas (Endraswara, 2011: 67). Pada pembacaan heuristik maka akan didapatkan "arti" dari sebuah teks. "Arti" adalah semua informasi dalam tataran mimetik yang disajikan oleh teks kepada pembaca, bersifat tekstual dan bersifat referensial sesuai dengan bahasa. Jadi, pembacaan heuristik adalah pembacaan semiotik tingkat pertama, yaitu berdasarkan struktur kebahasaan yang menerjemahkan "keanehan" katakata dan struktur bahasa agar sesuai dengan bahasa sehari-hari dan struktur kata berlaku. Pada tahap ini akan ditemukan arti dari puisi tersebut secara tekstual.

3. Pembacaan Hermeneutik 
Ayuni Diah Melani, Laelatur Rosyidah, Dhiya Restu Putra, Alfan Muhyar Faza - Analisis Makna dalam Geguritan "Iki Gurite Sepi" Karya Surtikanti (Suatu Kajian Semiotika Riffaterre)

Pembacaan hermeneutik dilakukan setelah pembacaan heuristik dan merupakan pembacaan sistem semiotik tingkat kedua. Pembacaan hermeneutik adalah pembacaan ulang (retroaktif) sesudah pembacaan heuristik dengan memberi konvensi sastranya (Pradopo, 2003: 135). Pada tahap pembacaan ini, puisi dimaknai secara keseluruhan. Tanda-tanda yang ditemukan dalam pembacaan heuristik ditemukan makna yang sebenarnya.

\section{Menemukan Matriks, Model dan Varian Puisi}

Matriks merupakan sumber seluruh makna yang ada dalam puisi. Biasanya matriks tidak hadir dalam teks puisi. Menurut Pradopo, matriks adalah kata kunci untuk menafsirkan puisi yang dikonkretisasikan. Dalam memahami sebuah puisi, Riffaterre mengumpamakan sebuah donat. Bagian donat terbagi menjadi dua yaitu daging donat dan bulatan kosong di tengah donat. Kedua bagian tersebut merupakan komponen yang tak terpisahkan serta saling mendukung. Bagian ruang kosong donat tersebut justru memegang peranan penting sebagai penopang donat. Maka sama halnya dengan puisi, ruang kosong pada puisi, sesuatu yang tidak hadir dalam teks puisi tersebut pada hakikatnya adalah penopang adanya puisi dan menjadi pusat makna yang penting untuk ditemukan. Ruang kosong tersebut adalah matriks. Matriks kemudian diaktualisasikan dalam bentuk model, sesuatu yangterlihat dalam teks puisi.

Model dapat pula dikatakan sebagai aktualisasi pertama dari matriks. Model merupakan kata atau kalimat yang dapat mewakili bait dalam puisi. Bentuk penjabaran dari model dinyatakan dalam varian-varian yang terdapat dalam tiap baris atau bait. Matriks dan model merupakan varian-varian dari struktur yang sama. Dengan kata lain, puisi merupakan perkembangan dari matriks menjadi model kemudian ditransformasikan menjadi varian-varian.

\section{Hipogram}

Riffaterre menyatakan bahwa setiap karya sastra biasanya baru memiliki makna yang penuh jika dikaitkan dengan karya sastra yang lain baik itu bersifat mendukung atau bertentangan. Hubungan antara suatu karya sastra 
Ayuni Diah Melani, Laelatur Rosyidah, Dhiya Restu Putra, Alfan Muhyar Faza - Analisis Makna dalam Geguritan "Iki Gurite Sepi" Karya Surtikanti (Suatu Kajian Semiotika Riffaterre)

dengan karya yang lain disebut hipogram. Hipogram juga dapat ditemukan dengan melihat keterkaitan suatu karya sastra dengan sejarahnya.

Metode yang digunakan daalam penelitian ini adalah deskriptif kualitatif. Metode ini digunakan sebagai metode pemaparan data yang terdapat dalam geguritan karya Surtikanti yang berjudul Geguritan Iki Gurite Sepi.Sumber data dalam penelitian ini naskah geguritan tersebut sebanyak 1 halaman.

Kemudian data dalam penelitian ini adalah kata, frasa dan kalimat yang terdapat dalam geguritan Geguritan Iki Gurite Sepi karya Surtikanti yang mengandung makna untuk dianalisis. Sumber data yang digunakan adalah naskah geguritan Geguritan Iki Gurite sepi sebanyak 1 halaman. Teknik pengumpulan data dilakukan dengan cara membaca dan menulis yang selanjutnya dianalisis dengan menggunakan teori semiotika Michael Riffaterre.

\section{HASIL DAN PEMBAHASAN}

Seperti yang dijelaskan sebelumnya pada latar belakang bahwa penulis akan menganalisis geguritan yang berjudul Geguritan Iki Gurite Sepi karya Surtikanti, maka penulis sajikan isi dari geguritan tersebut.

\section{Geguritan Iki, Gurite Sepi}

Karya Surtikanti

Ing ngendi geguritan iki bisa dak titipake

Jer kahanan wus ora nyawisake papan

Tembung - tembung edipeni

Trima sinampirake ing mega malang

Ora akeh maneh sing setya nganthi

Utawa ngonceki manik-manik ing sajrone

Dalah trima sinawang minangka

Ukara mati

Geguritan iki

Saderma guritan sepi

Ukara kang rinoncen awit kehanan

Kang mingget ati...

Yen ati tumlawung

Guritan lagi komanan papan

Yagene mengkono?

Emmmh,

Ora ana wangsulane

Mung enebe ati kang bisa mangsuli 
Berdasarkan penelitian yang telah dilakukan sebelumnya, didapatkan hasil mengenai makna dalam geguritan yang berjudul Geguritan Iki Gurite Sepi karya Surtikanti. Penjelasan mengenai makna yang terkandung dalam geguritan tersebut akan dipaparkan sebagai berikut.

\section{A. Ketidaklangsungan Ekspresi}

Menurut Michael Riffaterre puisi mengekspresikan konsep-konsep dan benda-benda secara tidak langsung. Sederhananya, puisi mengatakan satu hal dengan maksud hal lain. Hal inilah yang membedakan puisi dari bahasa pada umumnya. Puisi mempunyai cara khusus dalam membawakan maknanya (Faruk, 2012:141). Ketidaklangsungan itu disebabkan oleh tiga hal, yaitu penggantian arti (displacing of meaning), penyimpangan arti (distorting of meaning), dan penciptaan arti (creating of meaning).

1. Penggantian Arti (Displacing of Meaning)

Pada umumnya kata-kata kiasan menggantikan arti sesuatu yang lain, lebihlebih metafora dan metonimi. Dalam penggantian arti ini suatu kata (kiasan) berarti yang lain (tidak menurut arti sesungguhnya). Geguritan iki, Gurite Sepi ditemukan Ketidaklangsungan ekspresi berupa pergantian arti (Displacing of meaning) sebagai berikut:

\section{a. Metafora}

Baris ke-3: Tembung - tembung edipeni, kata edipeni merupakan persamaan dari kata indah.

Baris ke-4: Trima sinampirake ing mega malang, kata sinampirake merupakan metafora dari kata diungkapkan atau ditempatkan.

Baris ke-6: Utawa ngonceki manik-manik ing sajrone, kata ngonceki merupakan metafora dari kata mendalami atau mempelajari lebih lanjut.

Baris ke-11: Ukara kang rinoncen awit kahanan, kata rinoncen memiliki metafora dengan kata tersusun. 
Ayuni Diah Melani, Laelatur Rosyidah, Dhiya Restu Putra, Alfan Muhyar Faza - Analisis Makna dalam Geguritan "Iki Gurite Sepi" Karya Surtikanti (Suatu Kajian Semiotika Riffaterre)

Baris ke-13: Yen ati tumlawung, kata tumlawung bermetafor dengan kata gemuruh

Baris ke-14: Guritan lagi komanan papan, kata komanan memiliki metafora dengan kata ruang atau tempat

Baris ke-18: Mung enebe ati kang bisa mangsuli, kata enebe memiliki persamaan dengan kata diamnya.

b. Metonimia

Baris ke-4: mega, merupakan metonimia dari awang-awang.

Baris ke-6: manik-manik, merupakan metonimia dari keindahan.

\section{Perusakan atau Penyimpangan Makna (Distorsing of Meaning)}

Perusakan atau penyimpangan makna terjadi karena ambiguitas, kontradiksi, dan non-sense. Ambiguitas dapat terjadi pada kata, frasa, kalimat, maupun wacana yang disebabkan oleh munculnya penafsiran yang berbedabeda menurut konteksnya. Kontradiksi muncul karena adanya penggunaan ironi, paradoks, dan antitesis. Non-sense adalah kata-kata yang tidak mempunyai arti (sesuai kamus) tetapi mempunyai makna "gaib" sesuai dengan konteks (Salam, 2009:4). Dalam geguritan Geguritan Iki, Gurite Sepi tidak ditemukan perusakan atau penyimpangan makna.

\section{Penciptaan Makna (Creating or Meaning)}

Penciptaan makna berupa pemaknaan terhadap segala sesuatu yang dalam bahasa umum dianggap tidak bermakna, misalnya "simetri, rima, atau ekuivalensi semantik antara homolog-homolog dalam suatu stanza" (Riffaterre dalam Faruk, 2012:141).

Pada geguritan Geguritan Iki, Gurite Sepi ditemukan penciptaan arti antara lain: Baris ke-16: Emmmmh kata ini seolah olah menggambarkan suasana ketika sang penulis bertanya tentang keadaan nanti, namun tidak segera mendapatkan jawaban. 
Ayuni Diah Melani, Laelatur Rosyidah, Dhiya Restu Putra, Alfan Muhyar Faza - Analisis Makna dalam Geguritan "Iki Gurite Sepi" Karya Surtikanti (Suatu Kajian Semiotika Riffaterre)

\section{B. Heuristik dan Hermeneutik}

1. Pembacaan Heuristik

Langkah pertama yang dilakukan dalam menganalisis geguritan adalah dengan melakukan pembacaan heuristik. Artinya, pembacaan berdasarkan stuktur kebahasaan. Pembacaan ini dilakukan untuk menerjemahkan dan memperjelas arti kata-kata dan sinonim-sinonim dalam sebuah gurit.

Tabel 1. Hasil analisis pembacaan heuristik

\begin{tabular}{l|l}
\hline \multicolumn{2}{c}{ Geguritan Iki, Gurite Sepi } \\
\multicolumn{2}{c}{ Karya Surtikanti } \\
\hline $\begin{array}{l}\text { Ing ngendi geguritan iki bisa dak titipake } \\
\text { Jer kahanan wus ora nyawisake papan }\end{array}$ & Dimana puisi ini bisa kutitipkan \\
Tembung - tembung edipeni & Ketika keadaan sudah tidak mendukung \\
Trima sinampirake ing mega malang & Kata-kata indah \\
Ora akeh maneh sing setya nganthi & Hanya bisa kusampirkan di angkasa \\
Utawa ngonceki manik-manik ing sajrone & Tidak banyak lagi yang setia menunggu \\
Dalah trima sinawang minangka & Atau memahami keindahan didalamnya \\
Ukara mati & Tersisa hanya untuk dipandang \\
Geguritan iki & Kalimat mati \\
Saderma guritan sepi & Puisi ini \\
Ukara kang rinoncen awit kehanan & Hanya sebatas puisi sepi \\
Kang mingget ati... & Kalimat yang dirangkai sejak keadaan \\
Yen ati tumlawung & Yang menggetarkan hati....... \\
Guritan lagi komanan papan & Apabila hati bergemuruh \\
Yagene mengkono? & Baru tersisa ruang \\
Emmmh, & Bagaimana dengan nanti? \\
Ora ana wangsulane & Emhhhh, \\
Mung enebe ati kang bisa mangsuli & Tidak ada jawaban \\
\hline
\end{tabular}

\section{Pembacaan Hermeneutik}

Tindak lanjut setelah mencari ketidaklangsungan ekspresi dan pembacaan heuristik, langkah selanjutnya adalah melakukan pembacaan hermeneutik. Pada tahap pembacaan ini, puisi dimaknai secara keseluruhan. Tanda-tanda yang ditemukan dalam pembacaan heuristik ditemukan makna yang sebenarnya. Berikut adalah hasil pembacaan hermeneutik dari geguritan Geguritan Iki, Gurite Sepi. 
Ayuni Diah Melani, Laelatur Rosyidah, Dhiya Restu Putra, Alfan Muhyar Faza - Analisis Makna dalam Geguritan "Iki Gurite Sepi" Karya Surtikanti (Suatu Kajian Semiotika Riffaterre)

Geguritan Iki, Gurite Sepi yang merupakan karya Surtikanti. Setelah ditelaah lebih lanjut gurit ini menyuarakan isi hati penyair itu sendiri mengenai kegundahan hati, kegalauan-kegalauan yang ia rasakan terhadap keadaan saat itu. Seperti pada baris pertama yang berbunyi ing ngendi geguritan iki bisa daktitipkake dilanjutkan dengan Jer kahanan wus ora nyawisake papan. Kemudian dari situ bisa dimaknai bahwa ia bingung dimana lagi harus menyuarakan isi hati ataupun pikirannya. Sementara keadaan tidak mendukung. Suasana yang tergambarkan mungkin sedih, bingung, kalut, putus asa tidak tahu harus berbuat apa. Hingga akhirnya apa yang penyair pikirkan hanya bisa disampirake ing mega malang atau dibiarkan begitu saja tanpa diutarakan. Mengingat sudah tidak banyak lagi yang tertarik atau mungkin sudah terasingkan, terpinggirkan oleh zaman. Oleh karena itu syair ini diberi judul Gurite Sepi, hanya sebatas kalimat yang tercipta karena keadaan yang menggetarkan hati oleh gemuruhnya perasaan yang tidak karuan. Akankah setelah itu kembali mendapatkan perhatian? Entahlah, Sang penyair bertanya-tanya. Namun jawaban itu hanya bisa ditemukan didalam lubuk hati yang terdalam dengan keadaan tenang.

\section{Matriks, Model, dan Varian}

Saat menganalisis sebuah geguritan tentunya terdapat kata kunci yang bisa digunakan sebagai acuan. Menurut Pradopo, matriks adalah kata kunci untuk menafsirkan puisi yang dikonkretisasikan (2007: 299).

Matriks pada geguritan Geguritan Iki, Gurite Sepi adalah kesedihan, kebingungan penyair dalam mengungkapkan isi hati atau pikirannya. Kemudian matriks tersebut diwujudkan ke dalam model Geguritan dan Guritan. Lalu model-model tersebut dijabarkan dalam varian-varian sebagai berikut:
a. Dimana puisi ini bisa kutitipkan
b. Ketika keadaan sudah tidak mendukung
c. Hanya bisa kusampirkan di angkasa 
Ayuni Diah Melani, Laelatur Rosyidah, Dhiya Restu Putra, Alfan Muhyar Faza - Analisis Makna dalam Geguritan "Iki Gurite Sepi" Karya Surtikanti (Suatu Kajian Semiotika Riffaterre)
d. Bagaimana dengan nanti?
e. Emmmm, tidak ada jawaban

\section{Hipogram: Hubungan Intertekstual}

Acuan dalam memberikan apresiasi atau pemaknaan yang penuh pada karya sastra sebaiknya karya sastra tersebut disejajarkan dengan karya sastra lain yang menjadi hipogram atau latar belakang penciptaannya (Bernard dalam Salam, 2009:7). Dengan kata lain, hipogram adalah latar penciptaan suatu karya sastra yang dapat meliputi keadaan masyarakat, peristiwa dalam sejarah, atau alam dan kehidupan yang dialami oleh penyair.

Geguritan Geguritan Iki, Gurite Sepi memiliki hipogram kesedihan, kekalutan dan kebingungan penyair terhadap keadaan saat ini. Dimana zaman telah berubah kemudian ia hanya bisa mengungkapkannya lewat geguritan ini. Lalu memikirkan bagaimana keadaan nanti, namun tak kunjung mendapatkan jawaban.

\section{SIMPULAN}

Berdasarkan pembahasan yang telah diuraikan sebelumnya, maka dapat disimpulkan bahwa dalam geguritan yang berjudul Geguritan Iki, Gurite Sepi karya Surtikanti yang dianalisis menggunakan teori semiotika Riffaterre terdapat penanda dan petanda di dalamnya berupa 1) Ketidaklangusngan Ekspresi 2) Pembacaan heuristik dan hermeneutik 3) Matriks, model dan varian 4) Hipogram sehingga penciptaan makna dari geguritan tersebut bisa diketahui dan dipahami. Secara garis besar dapat dimaknai bahwa geguritan tersebut merupakan ungkapan hati sang penyair atas segala kegundahan dan kegelisahannya terhadap perkembangan zaman yang begitu pesatnya hingga kata-kata tak mampu mewakili yang kemudian berakhir menjadi sebatas sajak penghapus sepi. Hal ini berarti bahwa geguritan memang terbukti sebagai jembatan yang menyuarakan segala isi hati, keluh kesah juga media ekspresi jiwa seseorang yang tak terbatas oleh ruang dan waktu. Selain itu dapat 
Ayuni Diah Melani, Laelatur Rosyidah, Dhiya Restu Putra, Alfan Muhyar Faza - Analisis Makna dalam Geguritan "Iki Gurite Sepi" Karya Surtikanti (Suatu Kajian Semiotika Riffaterre)

diketahui pula keikutsertaan pengarang dalam memilih setiap diksi agar terkesan menyentuh dan mewakili keadaan. Selain itu, penelitian ini dapat memberikan manfaat bagi masyarakat untuk senantiasa terus melestarikan serta peduli terhadap budaya peninggalan leluhur dan makna yang terdapat dalam geguritan dapat diterapkan untuk hidup bermasyarakat. Selajutnya saran yang dapat penulis berikan yaitu penelitian ini diharapkan dapat membantu dalam mengkaji makna suatu karya sastra khususnya geguritan yang lain.

\section{DAFTAR PUSTAKA}

Endraswara, S. (2011). Metodologi penelitian sastra. Yogyakarta: Caps.

Faruk. (2012). Metode penelitian sastra: sebuah penjelajahan awal. Yogyakarta: Pustaka Pelajar.

Huri, R. M. (2017). Analisis semiotika Riffaterre dalam puisi dongeng Marsinah karya Sapardi Djoko Damono. Jurnal Bahasa dan Sastra, 5(1), 52-66.

Nasution, M. I. (2016). Semiotika. Padang: Fakultas Bahasa dan Seni Universitas Negeri Padang.

Padmosoekotjo. (1960). Ngengrengan kasusastran djawa. Jogjakarta: Hien Hoo Sing

Poerwadarminta. (1939). Bausastra Jawa. [Online]

https://www.sastra.org/bahasa-dan-budaya/kamus-dan-leksikon/789bausastra-jawa-poerwadarminta-1939-75-bagian-09-g diakses 18 Juni 2021 pukul 14.04 WIB.

Pradopo, R. D. (2003). Beberapa teori sastra, metode kritik, dan penerapannya. Yogyakarta: Pustaka Pelajar.

Pradopo, R. D. (2009). Pengkajian puisi: analisis strata norma dan analisis struktural dan semiotik. Yogyakarta: Gajah Mada University Press.

Pradopo, R. D. (2012). Pengkajian puisi: analisis strata norma dan analisis struktural dan semiotik. Yogyakarta: Gajah Mada University Press.

Purwadi. (2007). Sejarah sastra Jawa. Yogyakarta : Panji Pustaka.

Ratih, R. (2016). Teori dan aplikasi semiotik Michel Riffaterre. Yogyakarta: Pustaka Pelajar.

Riffaterre, M. (1978). Semiotic of poetry. London: Indiana Of University Perss. 
Ayuni Diah Melani, Laelatur Rosyidah, Dhiya Restu Putra, Alfan Muhyar Faza - Analisis Makna dalam Geguritan "Iki Gurite Sepi" Karya Surtikanti (Suatu Kajian Semiotika Riffaterre)

Salam. (2009). Pembelajaran menulis puisi dengan metode Michael Riffaterre. [online] http://gerbangpendidikan.blogspot.co.id/2009/01/pembelajaranmenulispuisi-dengan.html diakses 16 Juni 2021 pukul 22.37 WIB.

Taum, Y. Y. (2007). Semiotika Riffaterre dalam 'bulan ruwah' Subagio Sastrowardooyo. SINTESIS: Jurnal Ilmiah Kebudayaan, 5(1), 70-87.

Ulya, C. \& Suryanto, E. (2009). Meningkatkan kemampuan menulis puisi melalui pendekatan sinektik. PAEDAGOGIA, 12(1), 42-51.

Widodo, S.T. (2013). Buku ajar telaah puisi jawa modern. Surakarta: Fakultas Sastra dan Seni Rupa Universitas Sebelas Maret. 